\title{
Room temperature ethanol sensor with sub-ppm detection limit: Improving the optical response by using mesoporous silica foam
}

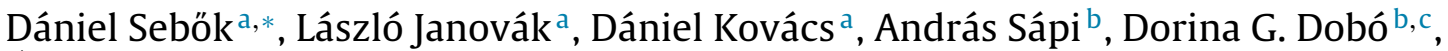 \\ Ákos Kukovecz ${ }^{\mathrm{b}, \mathrm{c}}$, Zoltán Kónya ${ }^{\mathrm{b}, \mathrm{d}}$, Imre Dékány ${ }^{\mathrm{a}, \mathrm{e}}$ \\ a Department of Physical Chemistry and Materials Science, University of Szeged, 1 Rerrich square, H-6720 Szeged, Hungary \\ ${ }^{\mathrm{b}}$ Department of Applied and Environmental Chemistry, University of Szeged, 1 Rerrich square, H-6720 Szeged, Hungary \\ c MTA-SZTE “Lendület” Porous Nanocomposites Research Group, University of Szeged, 1 Rerrich square, H-6720 Szeged, Hungary \\ d MTA-SZTE Reaction Kinetics and Surface Chemistry Research Group, University of Szeged, 1 Rerrich square, H-6720 Szeged, Hungary \\ e MTA-SZTE Supramolecular and Nanostructured Materials Research Group, University of Szeged, 8 Dóm square, H-6720 Szeged, Hungary
}

\section{A R T I C L E I N F O}

\section{Article history:}

Received 25 August 2016

Received in revised form

17 December 2016

Accepted 19 December 2016

Available online 21 December 2016

\section{Keywords:}

Thin film

RIfS

Mesoporous silica

Room temperature

Sub-ppm

Ethanol sensor

\begin{abstract}
A B S T R A C T
In this paper, the improvement in room temperature ethanol sensing characteristics of zinc peroxide $\left(\mathrm{ZnO}_{2}\right)$ based hybrid thin films is presented by the combination of the beneficial sensing properties of mesoporous materials and reflectometric interference spectroscopy (RIfS). The hybrid thin films were prepared by Layer-by-Layer (LbL) self-assembly method from $\mathrm{ZnO}_{2}$ nanoparticles, polyelectrolyte [poly(acrylic acid), PAA] and/or mesoporous silica (MPS). The expected improved sensing properties were attributed to the fractal properties and high specific surface area $\left(a^{s}\right)$ of the mesoporous coating/interlayer material, which was evidenced by small angle X-ray scattering (SAXS) and $\mathrm{N}_{2}$ sorption measurements $\left(a^{\mathrm{s}}>650 \mathrm{~m}^{2} / \mathrm{g}\right)$. The sensor tests showed that the detection limit of the thin films is in the sub-ppm range $(<500 \mathrm{ppb})$. Applying silica foam (SF) as surface coating or interlayer material in the sandwich-structured thin film $\left(\mathrm{ZnO}_{2} / \mathrm{SF}\right)$ improved the optical response ( $\Delta \mathrm{l}$ : wavelength shift) compared to the $\mathrm{ZnO}_{2} / \mathrm{PAA}$ thin layer, but the sensitivity showed non-linear characteristic and signal drift. The thin film with mixed structure $\left(\mathrm{ZnO}_{2} / \mathrm{PAA} / \mathrm{ZnO}_{2} / \mathrm{SF}\right)$ showed linear sensitivity $(\Delta \lambda / \Delta \mathrm{c}=0.6 \mathrm{~nm} / \mathrm{ppm})$ in the $0.5-12 \mathrm{ppm}$ range with an acceptable selectivity and stable baseline. Testing the sensor in extended (up to $40 \mathrm{ppm}$ ) concentration range showed only a slight quadratic deviation from linear behavior with $\mathrm{R}^{2}=0.9987$.
\end{abstract}

(C) 2016 Elsevier B.V. All rights reserved.

\section{Introduction}

Sensors for volatile organic compounds (VOCs) (e.g. alcohols, benzene etc.) play an important role in everyday life and industrial safety. Indisputable fact is that these chemical agents are harmful and unhealthy, so the detection of these molecules has a great importance in environmental and health protection, such as in air and water quality control, food industry or - especially in the case of ethanol - the "driving under influence" (DUI) control. Considering a comprehensive, although not complete overview of the articles published in recent years in ethanol sensors topic (Fig. 1) we can conclude that the principles, technical solutions, the materials used, the operating temperature ranges and concentration levels are fairly diversified. The most commonly used

\footnotetext{
* Corresponding author.

E-mail address: sebokd@chem.u-szeged.hu (D. Sebők).
}

sensor materials are $\mathrm{SnO}_{2}$ [1-3], $\mathrm{ZnO}$ [4-7], $\mathrm{SiO}_{2}$ [8], $\mathrm{In}_{2} \mathrm{O}_{3}$ [9] $\mathrm{TiO} 2$ [10], $\mathrm{Fe}_{2} \mathrm{O}_{3}$ [11,12] and other nanostructures [13-16], composites [17-25] or coatings [26,27]. The measurement principle is mainly based on the resistive method, but also capacitive $[8,15]$, optical [2,26-28], quartz crystal microbalance (QCM) [26,28] and piezo (self-powering device) $[7,21,22]$ applications can be found. Fig. 1 shows the principles, studied concentration ranges and operating temperatures presented in the works cited above. It can be seen that the studies can be divided into two major groups: room temperature (RT) and high temperature (around 200 and $300^{\circ} \mathrm{C}$ ) applications. Mainly electrical methods and mesoporous sensing materials are preferred in the latter case, thereby broad concentration ranges with excellent detection limits can be achieved. However, it has to be noted that VOC pollutants easily evaporate at room temperature and can be very harmful and carcinogenic already at low concentration. It can be seen on Fig. 1 that most of the RT technical solutions $[2,7,8,15,16,26-28]$ are able to detect ethanol vapour only above $10 \mathrm{ppm}$ concentration. In this work, 


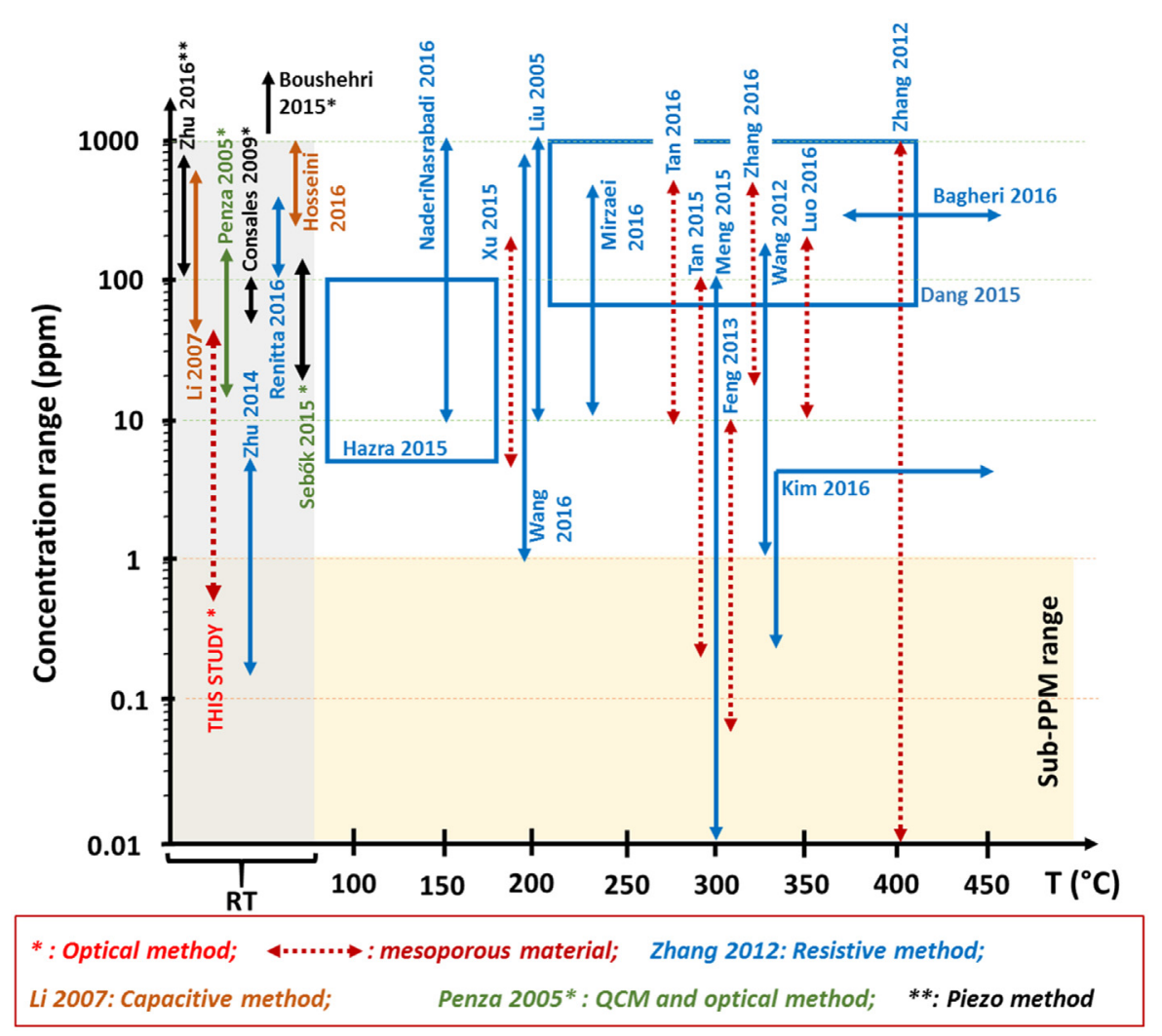

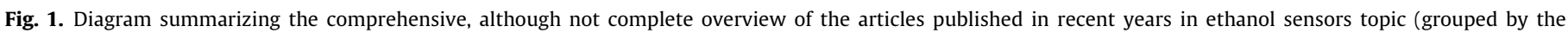
measurement principles, the studied concentration ranges and operating temperatures; note: room temperature has not detailed scale!).

we made an attempt to combine the beneficial sensing properties of mesoporous materials $[3,29,30]$ and reflectometric interference technique [31] to construct a highly sensitive ethanol sensor operating at room temperature.

Reflectometric interference spectroscopy [28,31-36] is an optical method which is based on the spectral (red) shift of the interference pattern reflected from a (few hundred nanometers of layer thickness) thin film. The wavelength shift is caused by the adsorption or adhesion of molecules or colloidal units, so it can be utilized in antigen-antibody reactions or to detect the adsorption of volatile compounds []. The sensor surface of RIfS technique can be prepared by using the wet colloid chemical procedure, the so-called Layer-by-Layer method [37,38]. The LbL method is widely used for thin film preparation directly from colloidal systems (nanoparticles, polymer solutions, etc.): it is an easy, non-instrumental technique and it results a homogeneous surface and well-ordered, transparent structure with controllable film thickness and a fine and porous microstructure [39], like the similar Langmuir-Blodgett method [40,41]. These are essential conditions for applying RIfS technique, and the sensitivity, as well as, the limit of detection can be improved by the addition of various surface-modifying agents [28,31].

In the present work we demonstrate the beneficial effect of using mesoporous silica materials on the sensitivity and detection limit of RIfS sensor in the gas phase. We show that applying mixed (nanoparticle/polyelectrolyte/mesoporous silica) nanostructure results linear sensitivity and sub-ppm ethanol detection limit without response drift, while both the response time and selectivity remain stable and adequate. Furthermore, firstly in this work we carried out reflection intensity measurement in addition to the wavelength shift monitoring: the two types of responses differ significantly, which may highlight - by further studies - the differences between the adsorption mechanisms onto the various surfaces.

\section{Experimental}

\subsection{Materials}

Zinc peroxide nanoparticles with an average diameter of $80 \mathrm{~nm}$ were synthesized by the photolysis of zinc acetate dehydrate $\left(\mathrm{C}_{4} \mathrm{H}_{6} \mathrm{O}_{4} \mathrm{Zn} \cdot 2 \mathrm{H}_{2} \mathrm{O}\right.$, Fluka, a.r.) described in [38]. Poly(acrylic acid) (PAA, $M_{W}=100000$, Sigma, a.r.) was used as a negatively charged polyelectrolyte. Furthermore, SBA-15 and silica foam were used as coatings or negatively charged interlayer materials. Synthesis of SBA-15 silica is well-known [42]. Mesoporous SF were prepared by a modified sol-gel route based on the technique suggested by Bagshaw [43]. In a typical synthesis, $13.9 \mathrm{~g}$ TEOS was slowly added to $30 \mathrm{~mL} 10 \mathrm{w} \%$ Triton X114 aqueous solution and the synthesis mixture were vigorously stirred for $24 \mathrm{~h}$. The obtained silica suspension was collected by vacuum filtration and left to dry at room temperature for $24 \mathrm{~h}$. The dried sample was introduced into a Teflon-lined stainless steel autoclave with a volume of $100 \mathrm{~mL}$ where $10 \mathrm{~mL}$ water was also added separately to ensure water vapour environment. After the assembly of the autoclave, it was held at $140^{\circ} \mathrm{C}$ for $24 \mathrm{~h}$. Finally, the silica foam was calcined in air at $450{ }^{\circ} \mathrm{C}$ for $4 \mathrm{~h}$.

\subsection{Thin film preparation}

Five types of hybrid thin films were prepared by using the $\mathrm{ZnO}_{2}$ nanoparticles, negatively charged PAA polyelectrolyte and the mesoporous silica samples (see Fig. 2): (1.) 20 zinc peroxide/poly (acrylic acid) bilayers $\left(\left[\mathrm{ZnO}_{2} / \mathrm{PAA}\right]_{20}\right) ;\left(2-3\right.$.) $\left[\mathrm{ZnO}_{2} / \mathrm{PAA}\right]_{20}$ films with silica foam and SBA-15 coatings $\left(\left[\mathrm{ZnO}_{2} / \mathrm{PAA}\right]_{20}+\mathrm{SF}\right.$ 


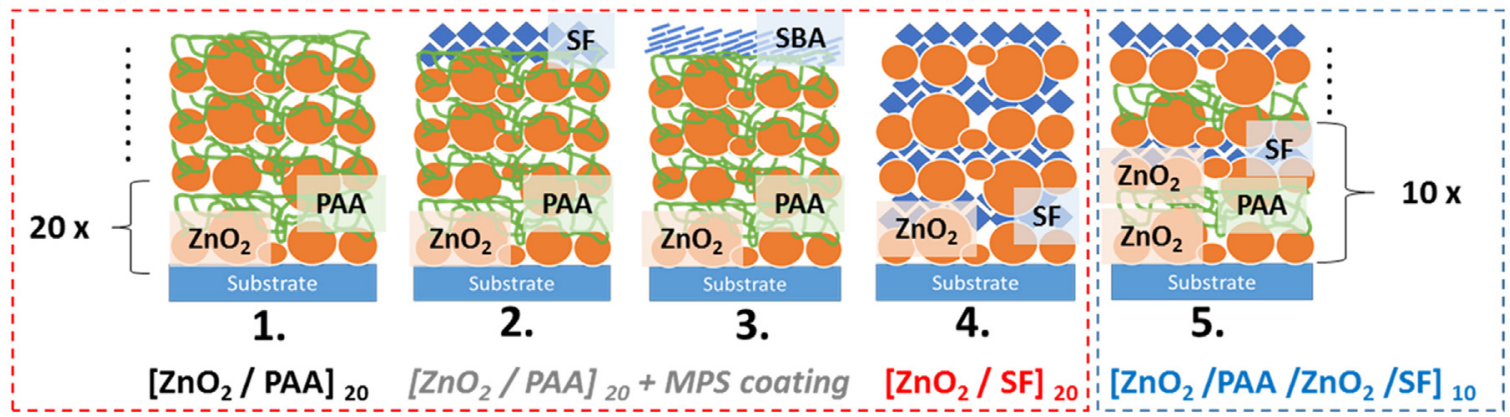

Fig. 2. The schematic view of the prepared and applied hybrid thin films.

and $\left.\left[\mathrm{ZnO}_{2} / \mathrm{PAA}\right]_{20}+\mathrm{SBA}\right)$; (4.) a thin film containing 20 bilayers of zinc peroxide/silica foam $\left(\left[\mathrm{ZnO}_{2} / \mathrm{SF}\right]_{20}\right)$ and (5.) a thin film containing 10 mixed, zinc peroxide/poly(acrylic acid)/zinc peroxide/silica foam multilayers $\left(\left[\mathrm{ZnO}_{2} / \mathrm{PAA} / \mathrm{ZnO}_{2} / \mathrm{SF}\right]_{10}\right)$. During pre-experiments, SBA-15 was not suitable as interlayer material in thin films consisting of 40 layers, therefore, it was only applied as a coating. The thin films were prepared by the LbL deposition method by the alternated adhesion/adsorption of $\mathrm{ZnO}_{2}$ nanoparticles, poly(acrylic acid) [44] and mesoporous silica nanostructures (SBA-15 and SF) on the surface of glass substrate (microscope slides, Marienfeld Superior, Germany). The thin film preparation was carried out by using $\mathrm{c}=8 \mathrm{~g} / \mathrm{L} \mathrm{ZnO} \mathrm{Zn}_{2}, \mathrm{c}=0.1 \mathrm{~g} / \mathrm{L}$ PAA and $\mathrm{c}=10 \mathrm{~g} / \mathrm{L}$ silica solutions. The immersion time was $10 \mathrm{~min}$ for each step, which was followed by rinsing with deionized water to remove the surplus (non-electrostatically attached) colloid units. During the coating process the previously prepared zinc-peroxide/poly(acrylic acid) hybrid films were immersed into the silica suspension and were dried without rinsing the surplus.

\subsection{Instrumental methods}

Transmission Electron Microscopy (TEM) measurements were carried out by a FEI TECNAI G ${ }^{2} 20$ X-Twin high-resolution transmission electron microscope (equipped with electron diffraction) operating at an accelerating voltage of $200 \mathrm{kV}$. The samples were drop-cast onto carbon film coated copper grids from ethanol suspension.

The specific surface area (BET method) and the total pore volume were determined by the BJH method using a Quantachrome NOVA 2200 gas sorption analyzer by $\mathrm{N}_{2}$ gas adsorption/desorption at $77 \mathrm{~K}$. Before the measurements, the samples were pre-treated in vacuum at $200^{\circ} \mathrm{C}$ for $2 \mathrm{~h}$. The density of the silica powders was measured using a helium

gas pycnometer (Micromeritics type 1305).

SAXS technique was used to investigate the fractal properties and structural parameters of the mesoporous silica components. SAXS curves were recorded with a slit-collimated Kratky compact small-angle system (KCEC/3 Anton-Paar KG, Graz, Austria) equipped with a position-sensitive detector (PSD $50 \mathrm{M}$ from $\mathrm{M}$. Braun AG Munich, Germany) containing 1024 channels $55 \mu \mathrm{m}$ in width. $\mathrm{CuK}_{\alpha}$ radiation $\left(\lambda_{\mathrm{CuK} \alpha}=0.1542 \mathrm{~nm}\right)$ was generated by a Philips PW1830 X-ray generator operating at $40 \mathrm{kV}$ and $30 \mathrm{~mA}$. The fractal dimension of a two-phase system can be determined by using the following equation: $I(h)=I_{0} h^{-p}$, where $h=4 \pi \sin \theta \lambda^{-1}$ is the scattering vector, $\theta$ is one-half of the scattering angle, $\lambda$ is the wavelength of $\mathrm{CuK}_{\alpha}$ radiation, $I(h)$ is the scattering curve, $I_{0}$ is the scattered intensity at $h=0$, and $p$ is the slope of the fitted line in the higher $h$-range (Porod regime) in log-log plot of the scattering curve. If $3<p<4$ then the sample is surface fractal, and the sample has mass fractal properties in the case of $1<p<3$. The specific surface area $\left(a^{s}\right)$ values were calculated by using equations in [45].
The optical properties of the thin films were studied by a Nanocalc 2000 spectrophotometer with ADC1000-USB A/D converter (Ocean Optics). The reflection spectra of the films were measured in a special, home-built test cell at detection angle of $45^{\circ}$. The thickness (d) and effective refractive index $\left(n_{1}\right)$ of the thin films were calculated based on the model presented in Fig. 3.a and by using (and fitting) Eq. (1) (more details in [38]):

$R\left(\lambda, n_{e}, d\right)=c_{1}+c_{2} \cdot \cos \left(\frac{4 \pi n_{1} d \cos \varepsilon_{1}}{\lambda}\right)$

where $\varepsilon_{1}$ is the angle of refraction at air/thin film interface, $\lambda$ is the wavelength, $c_{1}$ and $c_{2}$ are constants which contain the $t_{i j}$ and $r_{i j}$ transmission and reflection amplitudes calculated by Fresnel equations $(i, j=0,1,2$, see Fig. 3.a).

The same test cell was used during the sensorial tests in dynamic conditions (Fig. 3.b): it was connected to a gas flow system which consists of the carrier gas $\left(\mathrm{N}_{2}\right)$ holder, the temperature controlled liquid sample holder and a number of flow controllers (MFC) (ColeParmer, USA). The vapour concentration in the test cell can be controlled by the MFC units and V1-V5 valves via the mixing rate of pure and vapour containing $\mathrm{N}_{2}$ flows (the flow controllers can regulate maximum 3922, 844 and $49 \mathrm{~mL} / \mathrm{min}$ gas flow). The accuracy of the flow adjusting on the MFC scale is \pm 0.5 division, so the precision of the concentration is $\pm 0.04 \mathrm{ppm}$ or $\pm 0.68 \mathrm{ppm}$ in the case of the max. $49 \mathrm{~mL} / \mathrm{min}$ or the max. $844 \mathrm{~mL} /$ min devices, respectively. The ethanol dosage and rinsing $\left(\mathrm{N}_{2}\right)$ times were 3-3 min, alternately. The sensor responses, $\Delta \lambda(\mathrm{nm})$ and $\Delta \mathrm{R}$ (a.u.) were defined as the wavelength shift of the given extreme of the reflection spectra and the change of the reflection value corresponding to this extreme, respectively. The measurements in each concentration steps (475-11880 ppb) were repeated three times, the responses were determined as the average of the three value. During selectivity measurements $2 \mu \mathrm{L}$ of liquids (methanol, ethanol as alcohols; $n$-hexane as aliphatic; toluene, xylene as aromatic molecules) was dropped into the liquid sample holder (in this case $\mathrm{T}=70^{\circ} \mathrm{C}$ ) with a mixing rate of $4.9 \mathrm{~mL} / \mathrm{min}$ sub-branch and $1000 \mathrm{~mL} / \mathrm{min}$ main branch flow rates.

\section{Results and discussion}

\subsection{Characterization of the mesoporous silica materials}

The porosity, pore system characteristic and specific surface area are of great importance in the case of mesoporous adsorbents used in sensorial applications, therefore several structural parameters were determined and calculated by using SAXS technique. As it is known in the literature, SBA-15 has 2D hexagonally ordered pore system [38], which can be identified by TEM and SAXS technique (Fig. 4.a: A and B). Both measurements clearly show the pore structure; in the latter case the peaks at $h=0.705,1.235$ and $1.41 \mathrm{~nm}^{-1}$ correspond to the $1: \sqrt{ } 3: 2$ ratio, thereby the $\mathrm{P} 6 \mathrm{~mm}$ sym- 
a)
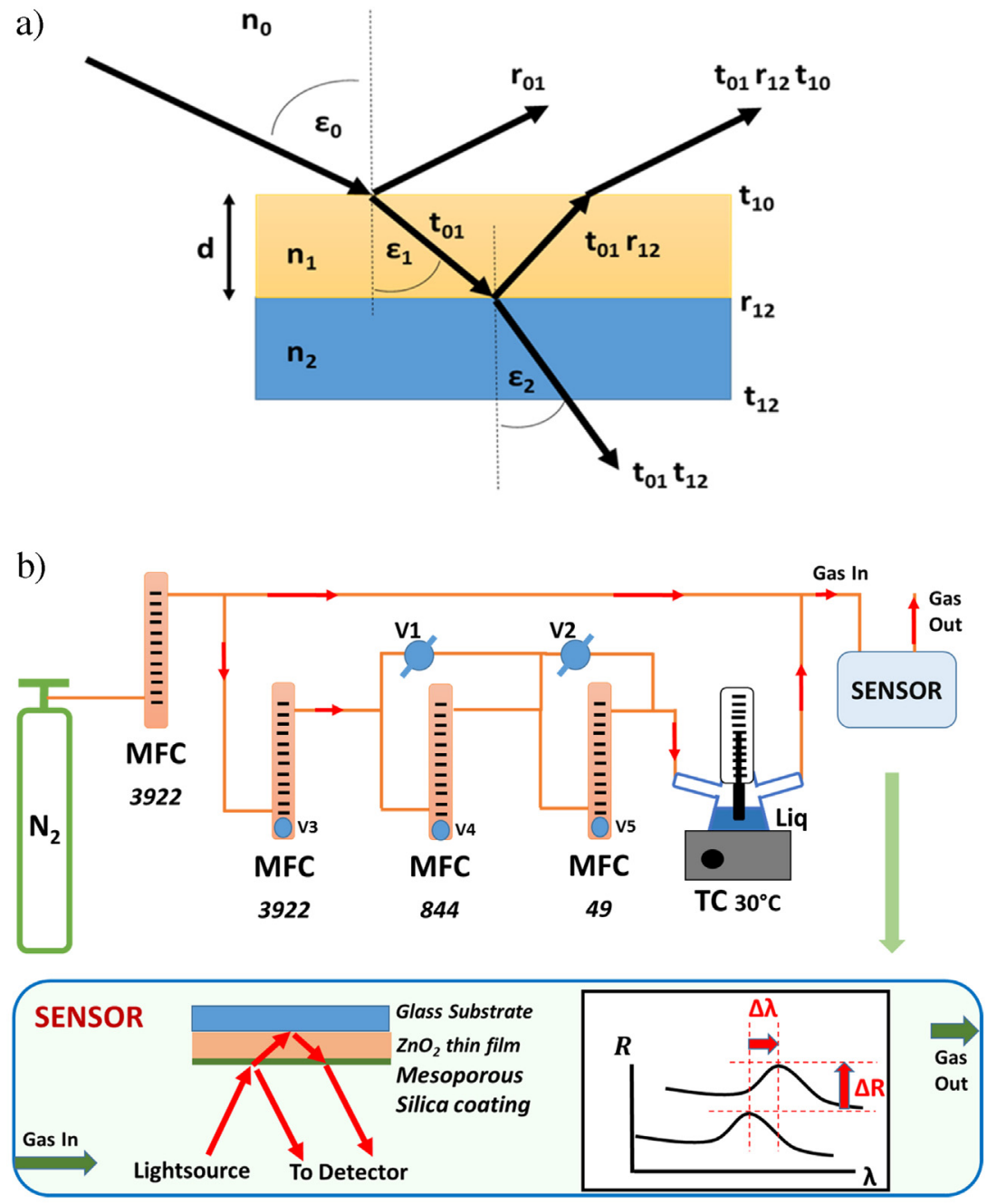

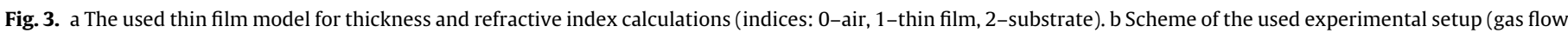
system and reflectometric test cell) and the measurement principle.

metry is clearly identified [46]. The double logarithmic plot of the scattering curve is suitable for determining the fractal properties of the material. In the case of SBA-15 the slope is approximately -2 in the higher $h$-range, which indicates a frame-like surface fractal structure, as well as, $\mathrm{p} \approx-3.5$ for SF sample is characteristic for the smooth surface feature of the mesocellular foam structure (see Fig. 4.a: C). The specific surface area values determined by SAXS measurements are 820 and $730 \mathrm{~m}^{2} / \mathrm{g}$ for SBA-15 and SF, respectively.

The $\mathrm{N}_{2}$ adsorption/desorption studies of the silica samples show isotherms with hysteresis loop and pore size distributions between 3 and $10 \mathrm{~nm}$ characteristic for mesoporous materials (Fig. 4.b). The specific surface areas and average pore diameters are $798 \mathrm{~m}^{2} \mathrm{~g}^{-1}$, $4.2 \mathrm{~nm}$ and $666 \mathrm{~m}^{2} \mathrm{~g}^{-1}, 4.6 \mathrm{~nm}$ for SBA-15 and SF, respectively. In summary, the SBA-15 has higher specific surface area, however the SF showed higher total pore volume $\left(V_{p}=0.76\right.$ and $1.30 \mathrm{~cm}^{3} \mathrm{~g}^{-1}$ for SBA-15 and SF, respectively). The overall conclusion is that although the structural and fractal nature of these mesoporous materials are significantly different, but the average pore diameters and specific surface areas are similar, and these values appear to be sufficiently high for considerable adsorption capacity and sensorial applications.

\subsection{Thin film characterization}

The recorded and fitted (in the $\lambda=550-850 \mathrm{~nm}$ range) reflection spectra and the calculated refractive index curves of three types of thin films (without coating) can be seen on Fig. 5. The layer thicknesses and effective refractive indices (at $\lambda=589 \mathrm{~nm}$ ) are $782 \mathrm{~nm}$ and $1.286,894 \mathrm{~nm}$ and $1.258,989 \mathrm{~nm}$ and 1.251 for $\left[\mathrm{ZnO}_{2} / \mathrm{PAA}\right]_{20}$, $\left[\mathrm{ZnO}_{2} / \mathrm{PAA} / \mathrm{ZnO}_{2} / \mathrm{SF}\right]_{10}$ and $\left[\mathrm{ZnO}_{2} / \mathrm{SF}\right]_{20}$, respectively. It can be established that using SF silica as interlayer material increases the thickness (d) and decreases the effective refractive index $\left(n_{1}\right)$ of the thin films. In our opinion, the main reasons for this is the following: these type of highly porous silica nanostructures significantly increase the micro- and macro-level porosity of the hybrid films, thereby considerably decrease the effective refractive index, while the polyelectrolyte forms ultrathin layers in the multilayer structure, thereby ensuring a closer packing for the $\mathrm{ZnO}_{2}$ nanoparticles. Increasing the porosity and forming thicker and porous interlayers in the sandwich-like structure explain the slightly lower refractive indices, higher film thicknesses and the advantageous effect in sensorial tests (presented later in 3.3). In the case of $\left[\mathrm{ZnO}_{2} / \mathrm{PAA}\right]_{20}+\mathrm{SF}$ and $\left[\mathrm{ZnO}_{2} / \mathrm{PAA}\right]_{20}+\mathrm{SBA}$ films the silica monolayer has no significant contribution to the refractive index and layer thickness, and given the fact that for these samples the coating had no significant 
A)

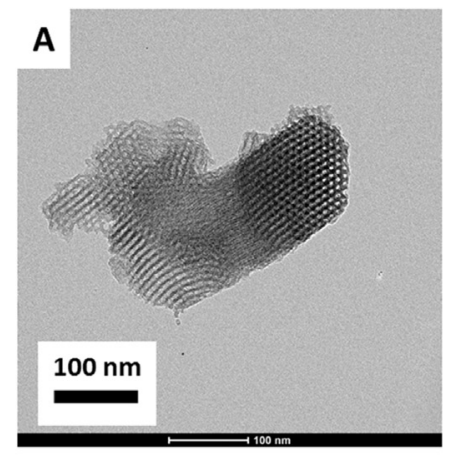

B)

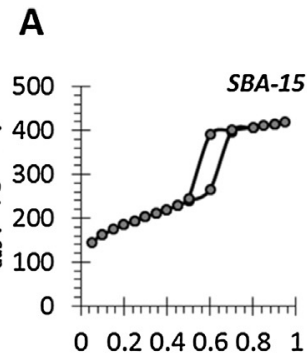

$\mathbf{p}_{\text {rel }}$

B
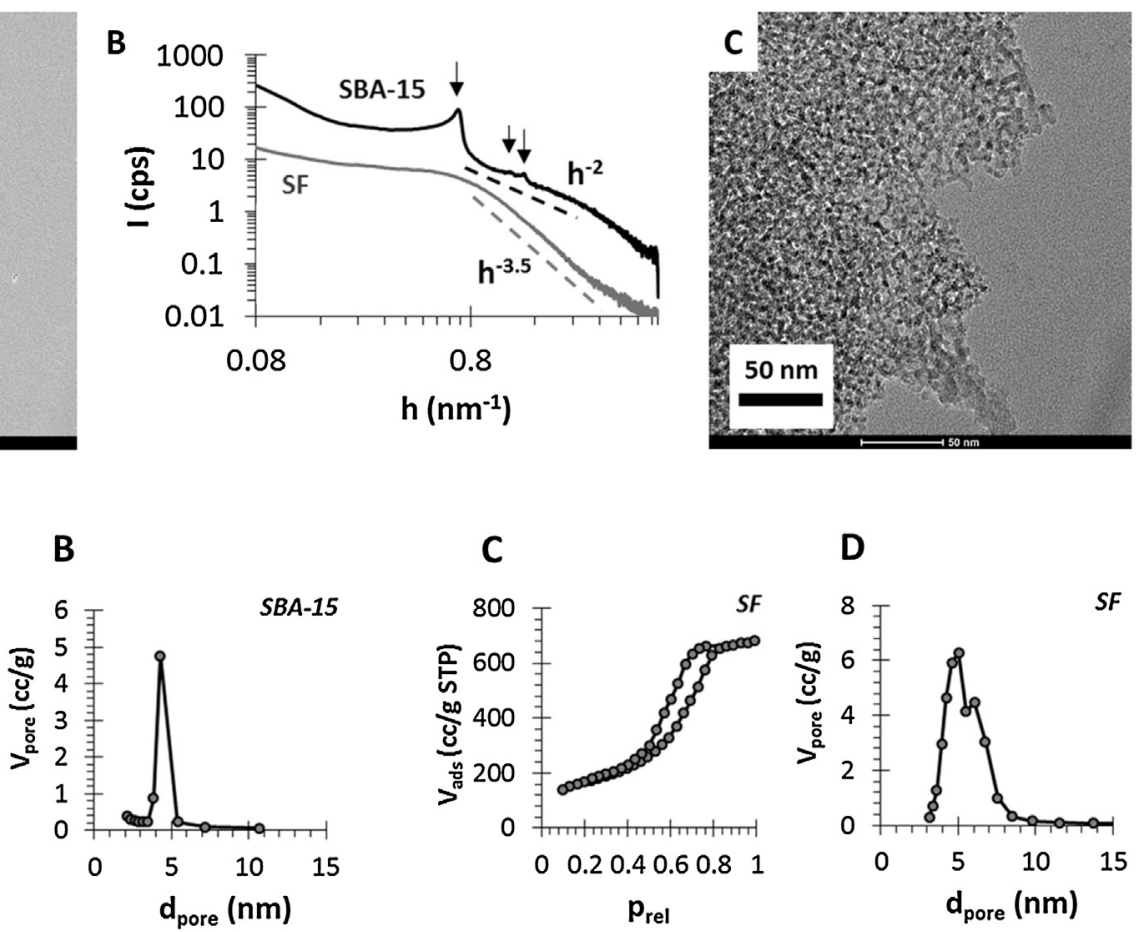

C

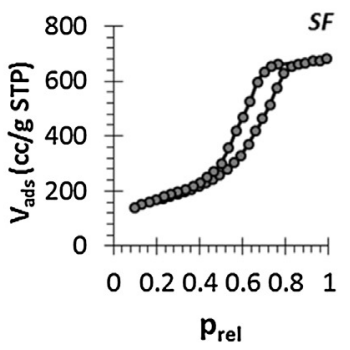

$S F$

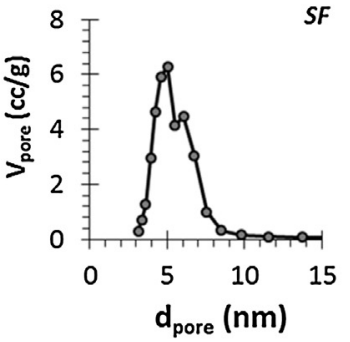

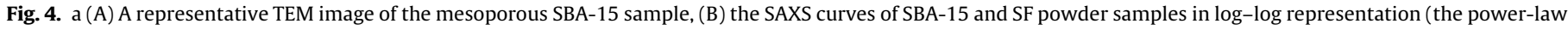

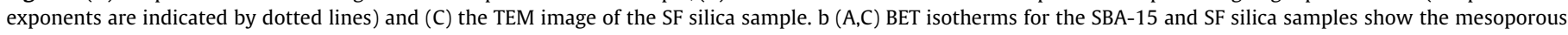
characteristic, (B,D) pore size distribution of SBA-15 and SF samples, respectively.
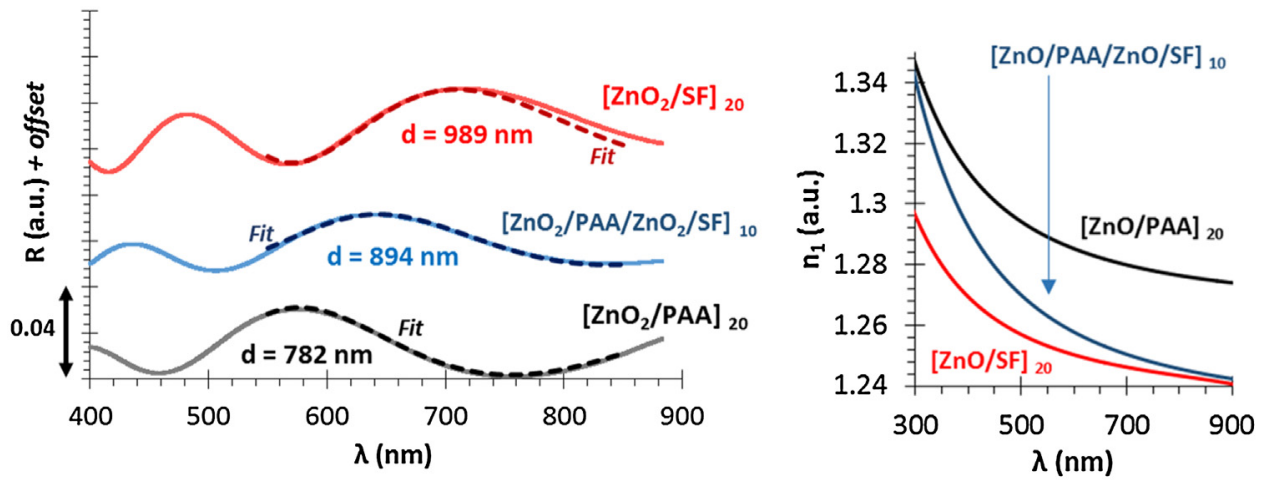

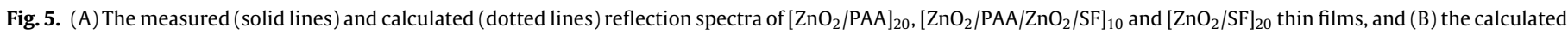
refractive index curves.

effect in the sensorial tests, the detailed discussion of the optical properties is ignored in this paragraph.

\subsection{Sensorial test of the hybrid thin films}

The thin films were subjected to reflectometric interference measurements for testing sensorial applications. The measurements were carried out by measuring the shift of the local minimum of reflected intensity near $\lambda=500 \mathrm{~nm}$ wavelength. It is $\lambda_{\min }=457 \mathrm{~nm}$ in the case of $\left[\mathrm{ZnO}_{2} / \mathrm{PAA}\right]_{20}$, and $\lambda_{\min }=507 \mathrm{~nm}$ and $568 \mathrm{~nm}$ for $\left[\mathrm{ZnO}_{2} / \mathrm{PAA} / \mathrm{ZnO}_{2} / \mathrm{SF}\right]_{10}$ and $\left[\mathrm{ZnO}_{2} / \mathrm{SF}\right]_{20}$, respectively (these values are valid in the $t=0$ measurement point). The raw results (sensorgrams), i.e., the $\Delta \lambda v s$. $t$ and $\Delta R$ vs. $t$ curves are presented in Fig. 6.a and b, respectively. Conspicuous differences can be noticed viewing either the two sensorgrams or the curves one by one. It can be immediately concluded that in the case of $\Delta \lambda$ curves the responses are positive because of the optical thickness increases due to the vapour adsorption. Significant signal drift can be observed in the case of $\mathrm{ZnO}_{2} / \mathrm{PAA}, \mathrm{ZnO} / \mathrm{PAA}+$ coating and $\mathrm{ZnO} / \mathrm{SF}$ thin films, which is rather disturbing phenomenon: should be drift compensation applied? In this case, not in general. $\mathrm{f}$ it is ignored then each measurement step (at the same concentration) results in higher response than the previous one and this fact makes impossible to accurately determine unknown concentrations. As it can be seen on the $\Delta \lambda$ calibration (response vs. concentration) curves (Fig. 7.a), we did not apply compensation, the responses increase with concentration, even if not linearly. However, in the case of $\left[\mathrm{ZnO}_{2} / \mathrm{PAA} / \mathrm{ZnO}_{2} / \mathrm{SF}\right]_{10}$ hybrid thin film response drift was not observed which resulted a linear $\Delta \lambda$ calibration curve $(0.586 \mathrm{~nm} / \mathrm{ppm})$. In the case of $\Delta R$ vs. $t$ curves (Fig. 6.b) positive response can be observed only in the case of $\left[\mathrm{ZnO}_{2} / \mathrm{PAA}\right]_{20}$ sensor, but if the thin film contains MPS (as interlayer material or 


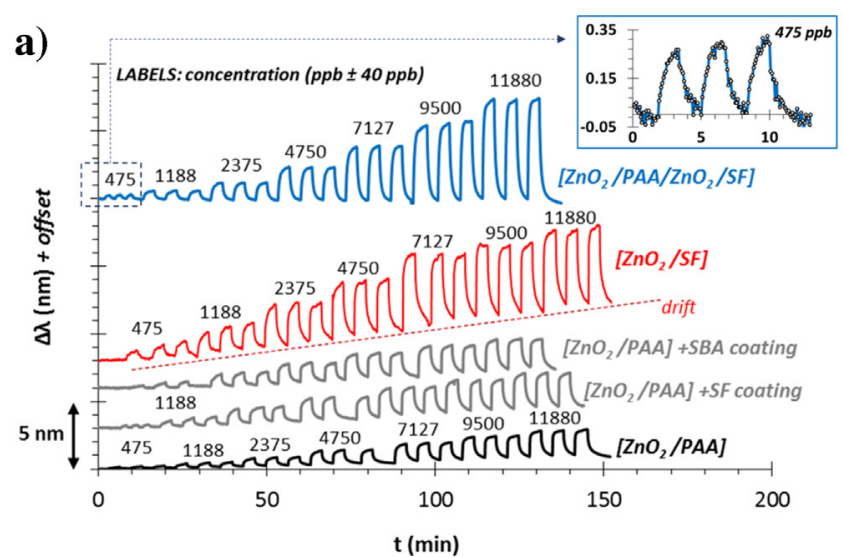

b)

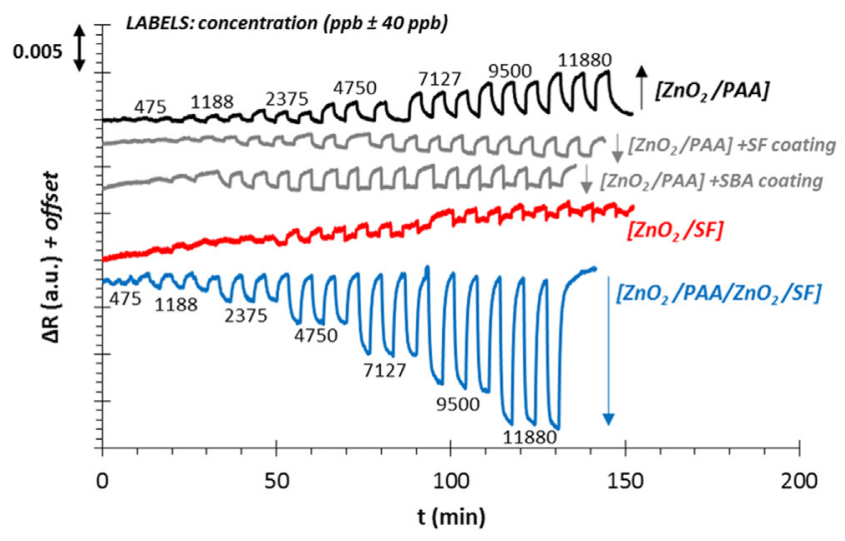

Fig. 6. a Ethanol sensing tests: $\Delta \lambda$ vs. $t$ curves for the tested thin films (labels: structure of the thin film and the ethanol concentration steps); inset: response of $\left[\mathrm{ZnO}_{2} / \mathrm{PAA} / \mathrm{ZnO}_{2} / \mathrm{SF}\right]_{10}$ mixed structure for $\mathrm{c}=475 \mathrm{ppb}$ EtOH. $\mathrm{b}$ Ethanol sensing tests: $\Delta R$ vs. $t$ curves for the tested thin films (labels: structure of the thin film and the ethanol concentration steps).

coating) then the reflectivity decreases due to the ethanol dosage. Furthermore, the responses of the coated thin films are lower than the original, as well as, the signal is not evaluable in the case of $\left[\mathrm{ZnO}_{2} / \mathrm{SF}\right]_{20}$ sensor surface. It can be stated that evaluable $\Delta \mathrm{R}$ signal and linear calibration can only be attributed to PAA containing multilayers (without coating), and the response can be improved by interlayered mesoporous silica foam (Fig. 7.b: for clarity, the absolute values of the responses are plotted). In summary, it was found that applying $\left[\mathrm{ZnO}_{2} / \mathrm{PAA}\right],\left[\mathrm{ZnO}_{2} / \mathrm{PAA}\right]+\mathrm{MPS}$ coating or $\left[\mathrm{ZnO}_{2} / \mathrm{SF}\right]$ structured thin layers mostly failed due to the signal drift and nonlinear sensitivity. The mixed structure of $\left[\mathrm{ZnO}_{2} / \mathrm{PAA} / \mathrm{ZnO}_{2} / \mathrm{SF}\right]$ was devoid of drift and showed linear calibration curves, so this type of hybrid (nanoparticle/polyelectrolyte/mesoporous silica) multilayer is an appropriate structure to apply as sensing surface in reflectometric interference sensor in gas phase. Furthermore, we can conclude that during RIfS measurements on solid/gas interface the monitoring of $\Delta R(t)$ beside the conventional $\Delta \lambda(t)$ signal may reveal the complexity of the adsorption processes and mechanisms in meso- and macroporous hybrid thin films.

Based on the presented results the $\left[\mathrm{ZnO}_{2} / \mathrm{PAA} / \mathrm{ZnO}_{2} / \mathrm{SF}\right]_{10}$ thin film was selected for further experiments, such as reproducibility, response time analysis and selectivity (Fig. 8). It can be stated that the sensors signal is well reproducible (Fig. 8A), the sensors response reaches the $90 \%$ of maximum value within $40 \mathrm{~s}$ and it is relaxed to $10 \%$ within $80 \mathrm{~s}$ ( $t_{90 \%}$ and $t_{10 \%}$ on Fig. $8 \mathrm{~B}$ ) (the total response and recovery times were $180-180$ s). Selectivity was tested by dropping $2 \mu \mathrm{L}$ of different liquids into a $70^{\circ} \mathrm{C}$ liquid sam-
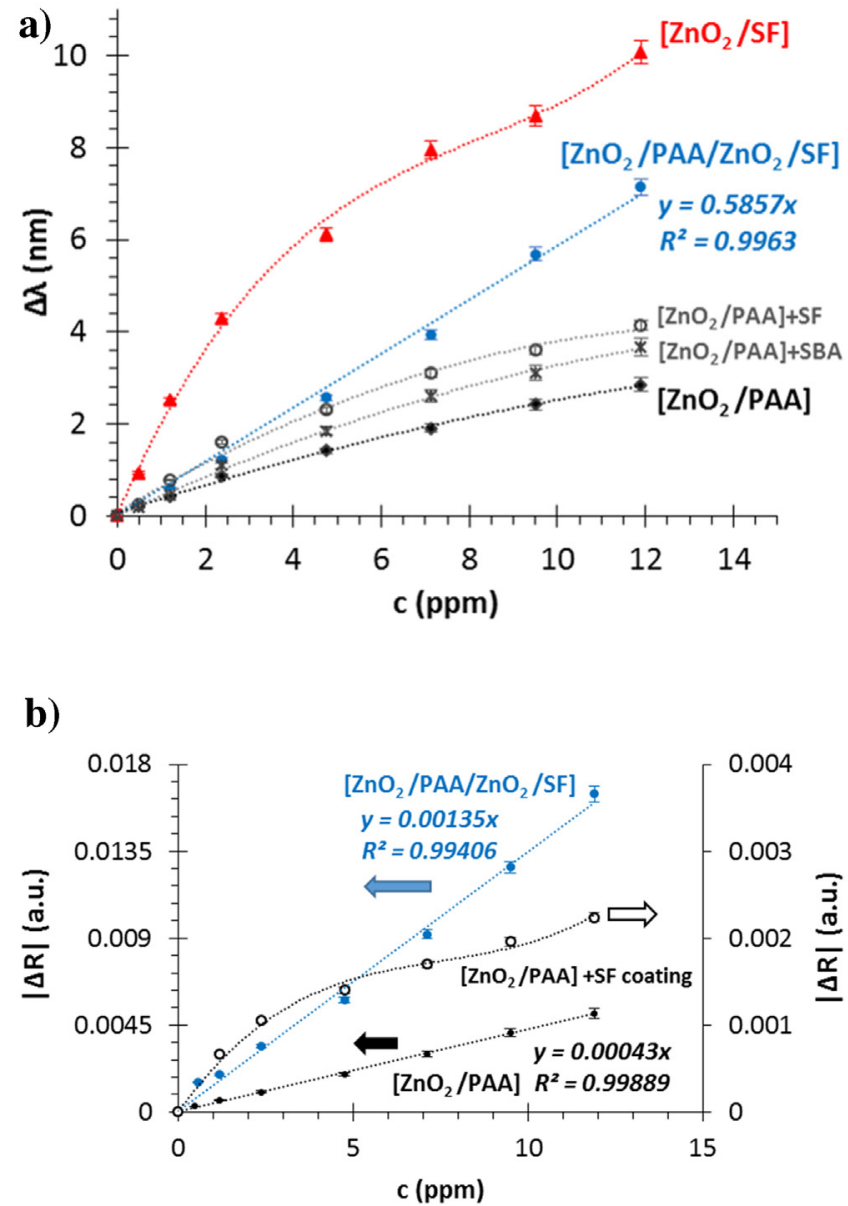

Fig. 7. a Ethanol sensing $\Delta \lambda(n m)$ vs. $c(p p m)$ calibration curves for the prepared thin layers (labels: structure of the thin films and calibration equation for $\left[\mathrm{ZnO}_{2} / \mathrm{PAA} / \mathrm{ZnO}_{2} / \mathrm{SF}\right]_{10}$ mixed structure). b Ethanol sensing $\Delta R v s . c(\mathrm{ppm})$ calibration curves for the prepared thin layers (labels: structure of the thin films and calibration equations for $\left[\mathrm{ZnO}_{2} / \mathrm{PAA}\right]_{20}$ and $\left[\mathrm{ZnO}_{2} / \mathrm{PAA} / \mathrm{ZnO}_{2} / \mathrm{SF}\right]_{10}$ mixed structures).

ple holder, which was connected into the $1000 \mathrm{~mL} / \mathrm{min}$ carrier gas stream towards the RIfS test cell. The liquids were methanol, ethanol, $n$-hexane, toluene and xylene. The studied thin films were $\left[\mathrm{ZnO}_{2} / \mathrm{PAA}\right]_{20}$ and $\left[\mathrm{ZnO}_{2} / \mathrm{PAA} / \mathrm{ZnO}_{2} / \mathrm{SF}\right]_{10}$ to investigate the effect of silica foam on the selectivity. It was established that in the case of $\mathrm{ZnO}_{2} / \mathrm{PAA} / \mathrm{SF}$ mixed structure 2-3 times higher response was observed for ethanol than for the other volatile organic compounds (VOC), although also the affinity to aromatic molecules increased compared to $\mathrm{ZnO}_{2} /$ PAA structure (Fig. $8 \mathrm{C}$ ).

\subsection{Extending the concentration range}

The sensor signal and calibration curve of $\mathrm{ZnO}_{2} / \mathrm{PAA} / \mathrm{ZnO}_{2} / \mathrm{SF}$ mixed structure in the low ppm range $(\sim 0.48-11.9 \mathrm{ppm})$ was presented on Fig. 6.a and 7.a, respectively. It was demonstrated that the lowest set and detected ethanol vapour concentration was $475 \pm 40 \mathrm{ppb}$, and the $\Delta \lambda v s$. $c$ calibration curve was linear in the $\mathrm{c}=475-11880 \mathrm{ppb}$ range. Next the $\left[\mathrm{ZnO}_{2} / \mathrm{PAA} / \mathrm{ZnO}_{2} / \mathrm{SF}\right]_{10}$ thin film was subjected to sensorial test in a higher, $c=2.46-37( \pm 0.68) \mathrm{ppm}$ range (Fig. 9.a). The concentration steps $(0-50 \mathrm{~min})$ were repeated after a $50 \mathrm{~min}$ long baseline stability test. The statement was that the sensor has a fairly stable baseline (without drift), but the $\Delta \lambda$ calibration curve showed a slight quadratic deviation from linear behavior (Fig. 9.b). The most important parameters are summarized in Table 1. 
Table 1

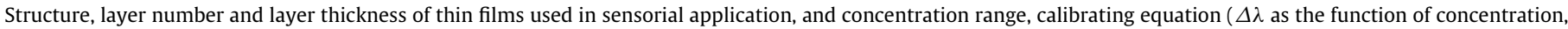

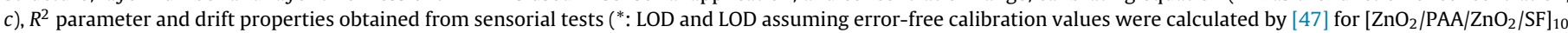

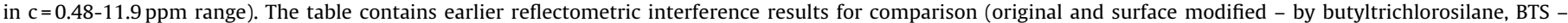
$\left[\mathrm{ZnO}_{2} / \text { poly(styrenesulfonate) }\right]_{20}$ thin films).

\begin{tabular}{|c|c|c|c|c|c|c|}
\hline Thin film & $\mathrm{d}(\mathrm{nm})$ & c range (ppm) & Calibration, $\Delta \lambda=\mathrm{f}(\mathrm{c})$ & $\mathrm{R}^{2}$ & Drift & LOD (ppm) \\
\hline$\left[\mathrm{ZnO}_{2} / \mathrm{PAA}\right]_{20}$ & 782 & $0.48-11.9$ & $-0.0086 c^{2}+0.339 c$ & 0.997 & yes & - \\
\hline$\left[\mathrm{ZnO}_{2} / \mathrm{SF}\right]_{20}$ & 989 & & 3rd order & - & yes & - \\
\hline$\left[\mathbf{Z n O}_{2} / \mathbf{P A A} / \mathbf{Z n O}_{2} / \mathbf{S F}\right]_{10}$ & 894 & & $0.586 c^{a}$ & 0.996 & no & $0.61^{\mathrm{b}}$ \\
\hline$\left[\mathbf{Z n O}_{2} / \mathbf{P A A} / \mathbf{Z n O}_{2} / \mathbf{S F}\right]_{10}$ & 894 & & $0.573 c^{c}$ & 0.996 & no & $\mathbf{0 . 6 3} 3^{\mathrm{d}}$ \\
\hline$\left[\mathrm{ZnO}_{2} / \mathrm{PAA} / \mathrm{ZnO}_{2} / \mathrm{SF}\right]_{10}$ & 894 & $2.46-37$ & $0.0107 c^{2}+0.427 c$ & 0.999 & no & - \\
\hline$\left[\mathrm{ZnO}_{2} / \mathrm{PSS}\right]_{20} \mathrm{e}^{-}$ & 514 & $0-128$ & $0.038 c+0.536$ & 0.998 & no & 29.2 \\
\hline$\left[\mathrm{ZnO}_{2} / \mathrm{PSS}\right]_{20}+\mathrm{BT}^{\mathrm{e}}$ & & $0-106$ & $0.331 c-0.652$ & 0.997 & no & 10.3 \\
\hline$\left[\mathrm{ZnO}_{2} / \mathrm{PSS}\right]_{20}+\mathrm{BTS}^{\mathrm{e}}$ & & $0-50$ & $0.293 c-0.140$ & 0.999 & no & 5.5 \\
\hline
\end{tabular}

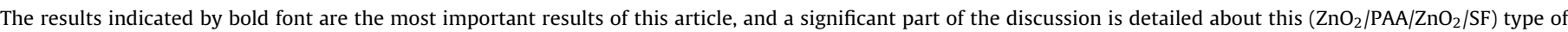
nanostructure.

a calibration by using continuously selected amounts of concentrations.

b LODefc (assuming error-free calibration) $=0.27 \mathrm{ppm}$; [47].

c calibration by using randomly selected amounts of concentrations.

d LODefc (assuming error-free calibration) $=0.29 \mathrm{ppm}$; [47].

e D. Sebők, I. Dékány, Sensor. Actuat. B-Chem. 206 (2015) 435-442. [28].

A

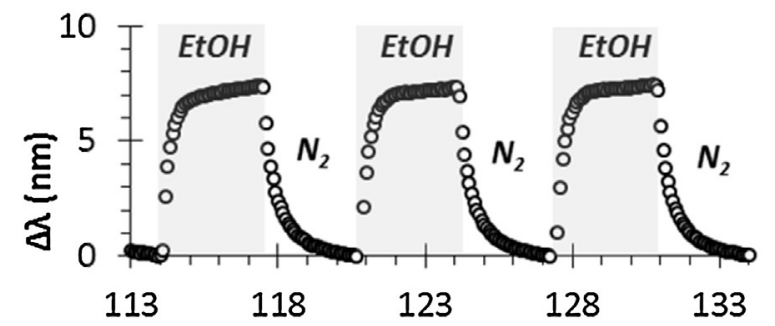

B
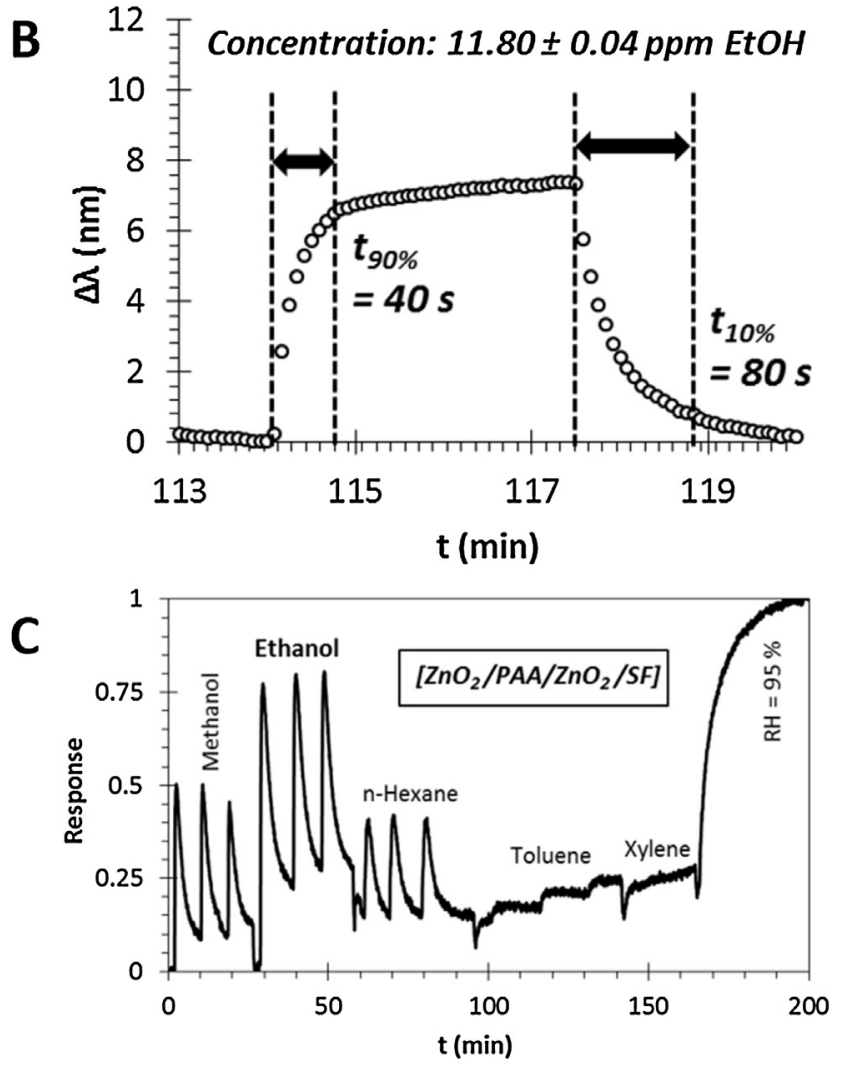

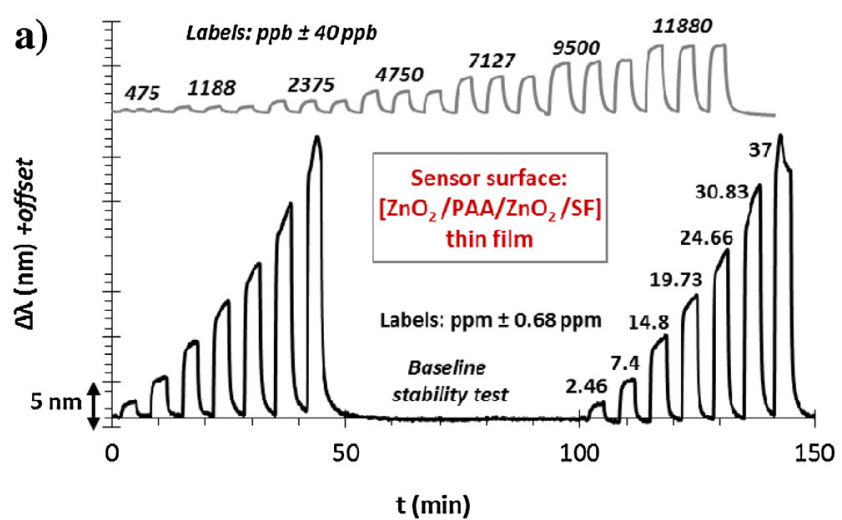

b)

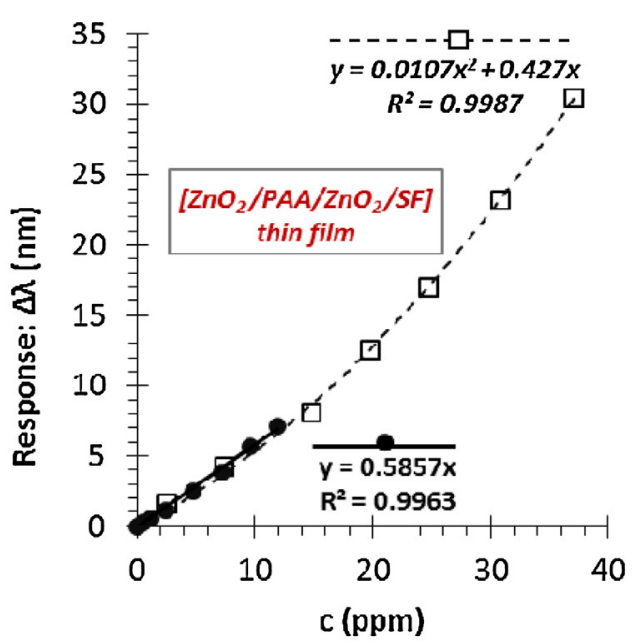

Fig. 9. a Ethanol sensing test in extended concentration range: $\Delta \lambda v$ s. $t$ curves for $\left[\mathrm{ZnO}_{2} / \mathrm{PAA} / \mathrm{ZnO}_{2} / \mathrm{SF}\right]_{10}$ thin film in the $2.46-37 \mathrm{ppm}$ range (black line) compared to the $0.48-11.9 \mathrm{ppm}$ concentration range (gray line) (labels: ethanol concentration steps). b Ethanol sensing test in extended concentration range: $\Delta \lambda(\mathrm{nm}) v \mathrm{~s} . \mathrm{c}(\mathrm{ppm})$ calibration curves for $\left[\mathrm{ZnO}_{2} / \mathrm{PAA} / \mathrm{ZnO}_{2} / \mathrm{SF}\right]_{10}$ thin film in the $2.46-37 \mathrm{ppm}$ range (white squares) compared to the $0.48-11.9 \mathrm{ppm}$ concentration range (black circles) (labels: calibration equations).

Fig. 8. Response analysis for $\left[\mathrm{ZnO}_{2} / \mathrm{PAA} / \mathrm{ZnO}_{2} / \mathrm{SF}\right]_{10}$ mixed structure: (A) reproducibility, (B) response and recovery times and (C) selectivity compared to $\left[\mathrm{ZnO}_{2} / \mathrm{PAA}\right]_{20}$ thin film. 


\section{Conclusions}

In this work we successfully combined the beneficial sensing properties of mesoporous silica materials and reflectometric interference technique to construct a highly sensitive ethanol sensor operating at room temperature. The structural parameters and fractal properties of the silica samples (SBA-15 and silica foam) were studied by TEM, BET and SAXS techniques: latter methods showed that the specific surface area of the MPSs is over $650 \mathrm{~m}^{2} / \mathrm{g}$. The three types of hybrid thin films, namely $\mathrm{ZnO}_{2}$ /polyelectrolyte (PAA), $\mathrm{ZnO}_{2} /$ mesoporous silica foam (SF) and a mixed, $\mathrm{ZnO}_{2} / \mathrm{PAA} / \mathrm{ZnO}_{2} / \mathrm{SF}$ structures were subjected to sensorial tests in the gas phase. We showed that the detection limit of the sensor is sub-ppm $(<500 \mathrm{ppb})$, but only the mixed $\left(\mathrm{ZnO}_{2} / \mathrm{PAA} / \mathrm{ZnO}_{2} / \mathrm{SF}\right)$ nanostructure showed linear sensitivity in the $0.4-11.9 \mathrm{ppm}$ range without response drift, while both the response time and selectivity remain reasonable good. Testing the sensor in extended (up to $37 \mathrm{ppm}$ ) concentration range showed a slight quadratic deviation from linear behavior. In the future the functionalization of the sensor surface by different modifying agents is expected to enhance the selectivity and sensitivity of the sensor.

\section{Acknowledgements}

The authors are very thankful for the financial support from The Hungarian Scientific Research Fund (NKFIH OTKA) PD 116224 and GINOP-2.3.2-15-2016-00013. The work was earlier partially supported by the European Union and the State of Hungary, co-financed by the European Social Fund in the framework of TÁMOP4.2.4. A/2-11-1-2012-0001 'National Excellence Program'. AS is grateful for the support of János Bolyai Research Scholarship of the Hungarian Academy of Sciences.

\section{Appendix A. Supplementary data}

Supplementary data associated with this article can be found, in the online version, at http://dx.doi.org/10.1016/j.snb.2016.12.097.

\section{References}

[1] X. Feng, J. Jiang, H. Ding, R. Ding, D. Luo, J. Zhu, Y. Feng, X. Huang, Carbon-assisted synthesis of mesoporous $\mathrm{SnO} 2$ nanomaterial as highly sensitive ethanol gas sensor, Sensor. Actuat. B-Chem. 183 (2013) 526-534, http://dx.doi.org/10.1016/j.snb.2013.04.006.

[2] S. Sharifpour-Boushehri, S.M. Hosseini-Golgoo, M.-H. Sheikhi, A low cost and reliable fiber optic ethanol sensor based on nano-sized $\mathrm{SnO}_{2}$, Opt. Fiber Technol. 24 (2015) 93-99, http://dx.doi.org/10.1016/j.yofte.2015.05.002.

[3] W. Tan, Q. Yu, X. Ruan, X. Huang, Design of $\mathrm{SnO}_{2}$-based highly sensitive ethanol gas sensor based on quasi molecular-cluster imprinting mechanism, Sensor. Actuat. B-Chem. 212 (2015) 47-54, http://dx.doi.org/10.1016/j.snb. 2015.01.035.

[4] L. Zhang, J. Zhao, H. Lu, L. Li, J. Zheng, H. Li, Z. Zhu, Facile synthesis and ultrahigh ethanol response of hierarchically porous $\mathrm{ZnO}$ nanosheets, Sensor. Actuat. B-Chem. 161 (2012) 209-215, http://dx.doi.org/10.1016/j.snb.2011. 10.021.

[5] L. Wang, Y. Kang, X. Liu, S. Zhang, W. Huang, S. Wang, ZnO nanorod gas sensor for ethanol detection, Sensor. Actuat. B-Chem. 162 (2012) 237-243, http://dx. doi.org/10.1016/j.snb.2011.12.073.

[6] F. Meng, S. Ge, Y. Jia, B. Sun, Y. Sun, C. Wang, H. Wu, Z. Jin, M. Li, Interlaced nanoflake-assembled flower-like hierarchical ZnO microspheres prepared by bisolvents and their sensing properties to ethanol, J. Alloy. Compd. 632 (2015) 645-650, http://dx.doi.org/10.1016/j.jallcom.2015.01.289.

[7] P. Wang, Y. Fu, B. Yu, Y. Zhao, L. Xing, X. Xue, Realizing room-temperature self-powered ethanol sensing of $\mathrm{ZnO}$ nanowire arrays by combining their piezoelectric, photoelectric and gas sensing characteristics, J. Mater. Chem. A 3 (2015) 3529-3535, http://dx.doi.org/10.1039/C4TA06266C.

[8] X.J. Li, S.J. Chen, C.Y. Feng, Characterization of silicon nanoporous pillar array as room-temperature capacitive ethanol gas sensor, Sensor. Actuat. B-Chem. 123 (2007) 461-465, http://dx.doi.org/10.1016/j.snb.2006.09.021.

[9] S. Zhang, P. Song, H. Yan, Z. Yang, Q. Wang, A simple large-scale synthesis of mesoporous $\mathrm{In}_{2} \mathrm{O}_{3}$ for gas sensing applications, Appl. Surf. Sci. 378 (2016) 443-450, http://dx.doi.org/10.1016/j.apsusc.2016.04.019.
[10] A. Hazra, K. Dutta, B. Bhowmik, P. Bhattacharyya, Repeatable low-ppm ethanol sensing characteristics of $\mathrm{p}-\mathrm{TiO}_{2}$-based resistive devices, IEEE sens, J. 15 (2015) 408-416, http://dx.doi.org/10.1109/JSEN.2014.2345575.

[11] A. Mirzaei, K. Janghorban, B. Hashemi, M. Bonyani, S.G. Leonardi, G. Neri, Highly stable and selective ethanol sensor based on $\alpha-\mathrm{Fe}_{2} \mathrm{O}_{3}$ nanoparticles prepared by Pechini sol-gel method, Ceram. Int. 42 (2016) 6136-6144, http:// dx.doi.org/10.1016/j.ceramint.2015.12.176.

[12] J. Tan, J. Chen, K. Liu, X. Huang, Synthesis of porous $\left(-\mathrm{Fe}_{2} \mathrm{O}_{3}\right.$ microrods via in situ decomposition of $\mathrm{FeC}_{2} \mathrm{O}_{4}$ precursor for ultra-fast responding and recovering ethanol gas sensor Sensor, Actuat. B-Chem. 230 (2016) 46-53, http://dx.doi.org/10.1016/j.snb.2016.02.012.

[13] J. Liu, X. Wang, Q. Peng, Y. Li, Vanadium pentoxide nanobelts: highly selective and stable ethanol sensor materials, Adv. Mater. 17 (2005) 764-767, http:// dx.doi.org/10.1002/adma.200400993.

[14] T.T. Le Dang, M. Tonezzer, Polycrystalline NiO nanowires: scalable growth and ethanol sensing, Proc. Eng. 120 (2015) 427-434, http://dx.doi.org/10.1016/j. proeng.2015.08.658 (Eurosensors 2015).

[15] M.S. Hosseini, S. Zeinali, M.H. Sheikhi, Fabrication of capacitive sensor based on Cu-BTC (MOF-199) nanoporous film for detection of ethanol and methanol vapors, Sensor. Actuat. B-Chem. 230 (2016) 9-16, http://dx.doi.org/10.1016/j. snb.2016.02.008.

[16] A. Renitta, K. Vijayalakshmi, A novel room temperature ethanol sensor based on catalytic Fe activated porous $\mathrm{WO}_{3}$ microspheres, Catal. Commun. 73 (2016) 58-62, http://dx.doi.org/10.1016/j.catcom.2015.10.014.

[17] Z. Zhu, C.-T. Kao, R.-J. Wu, A highly sensitive ethanol sensor based on ${\mathrm{Ag} @ \mathrm{TiO}_{2}}$ nanoparticles at room temperature, Appl. Surf. Sci. 320 (2014) 348-355, http://dx.doi.org/10.1016/j.apsusc.2014.09.108.

[18] X.L. Xu, Y. Chen, S.Y. Ma, W.Q. Li, Y.Z. Mao, S.H. Yan, T. Wang, Facile synthesis of $\mathrm{SnO}_{2}$ mesoporous tubular nanostructure with high sensitivity to ethanol, Mater. Lett. 143 (2015) 55-59, http://dx.doi.org/10.1016/j.matlet.2014.12. 064.

[19] M. Bagheri, A.A. Khodadadi, A.R. Mahjoub, Y. Mortazavi, Gallia-ZnO nanohybrid sensors with dramatically higher sensitivity to ethanol in presence of CO, methane and VOCs, Sensor. Actuat. B-Chem 223 (2016) 576-585, http://dx.doi.org/10.1016/j.snb.2015.09.137.

[20] S. Luo, Y. Shen, Z. Wu, M. Cao, F. Gu, L. Wang, Enhanced ethanol sensing performance of mesoporous Sn-doped ZnO, Mat. Sci. Semicon. Proc. 41 (2016) 535-543, http://dx.doi.org/10.1016/j.mssp.2015.10.001.

[21] M. NaderiNasrabadi, Y. Mortazavi, A.A. Khodadadi, Highly sensitive and selective $\mathrm{Gd}_{2} \mathrm{O}_{3}$-doped $\mathrm{SnO}_{2}$ ethanol sensors synthesized by a high temperature and pressure solvothermal method in a microreactor, Sensor. Actuat. B-Chem. 230 (2016) 130-139, http://dx.doi.org/10.1016/j.snb.2016. 02.045.

[22] D. Zhu, Y. Fu, W. Zang, Y. Zhao, L. Xing, X. Xue, Room-temperature self-powered ethanol sensor based on the piezo-surface coupling effect of heterostructured $\alpha-\mathrm{Fe}_{2} \mathrm{O}_{3} / \mathrm{ZnO}$ nanowires, Mater. Lett. 166 (2016) 288-291, http://dx.doi.org/10.1016/j.matlet.2015.12.106.

[23] Y. Lin, P. Deng, Y. Nie, Y. Hu, L. Xing, Y. Zhang, X. Xue, Room-temperature self-powered ethanol sensing of a $\mathrm{Pd} / \mathrm{ZnO}$ nanoarray nanogenerator driven by human finger movement, Nanoscale 6 (2014) 4604-4610, http://dx.doi.org/ 10.1039/C3NR06809A.

[24] B.-Y. Kim, J.S. Cho, J.-W. Yoon, C.W. Na, C.-S. Lee, J.H. Ahn, Y.C. Kang, J.-H. Lee, Extremely sensitive ethanol sensor using Pt-doped $\mathrm{SnO}_{2}$ hollow nanospheres prepared by Kirkendall diffusion, Sensor. Actuat. B-Chem. 234 (2016) (2016) 353-360, http://dx.doi.org/10.1016/j.snb.2016.05.002.

[25] Q. Wang, X. Li, F. Liu, Y. Sun, C. Wang, X. Li, P. Sun, J. Lin, G. Lu, Three-dimensional flake-flower Co/Sn oxide composite and its excellent ethanol sensing properties, Sensor. Actuat. B-Chem. 230 (2016) 17-24, http:// dx.doi.org/10.1016/j.snb.2016.01.147.

[26] M. Penza, G. Cassano, P. Aversa, F. Antolini, A. Cusano, M. Consales, M. Giordano, L. Nicolais, Carbon nanotubes-coated multi-transducing sensors for VOCs detection, Sens. Actuators B: Chem. 111-112 (2005) 171-180, http://dx. doi.org/10.1016/j.snb.2005.06.055.

[27] M. Consales, A. Crescitelli, M. Penza, P. Aversa, P. Delli Veneri, M. Giordano, A. Cusano, SWCNT nano-composite optical sensors for VOC and gas trace detection, Sensor. Actuat. B-Chem. 138 (2009) 351-361, http://dx.doi.org/10. 1016/j.snb.2009.02.041.

[28] D. Sebök, I. Dékány, $\mathrm{ZnO}_{2}$ nanohybrid thin film sensor for the detection of ethanol vapour at room temperature using reflectometric interference spectroscopy, Sensor. Actuat. B-Chem. 206 (2015) 435-442, http://dx.doi.org/ 10.1016/j.snb.2014.09.087.

[29] Q. Qi, T. Zhang, X. Zheng, L. Wan, Preparation and humidity sensing properties of Fe-doped mesoporous silica SBA-15, Sensor. Actuat. B-Chem 135 (2008) 255-261, http://dx.doi.org/10.1016/j.snb.2008.08.036.

[30] Y. Liu, J. Chen, W. Li, D. Shen, Y. Zhao, M. Pal, H. Yu, B. Tu, D. Zhao, Carbon functionalized mesoporous silica-based gas sensors for indoor volatile organic compounds, J. Colloid Interf. Sci. 477 (2016) 54-63, http://dx.doi.org/ 10.1016/j.jcis.2016.05.040.

[31] D. Sebők, Edit Csapó, Nóra Ábrahám, Imre Dékány, Reflectometric measurement of $n$-hexane adsorption on $\mathrm{ZnO}_{2}$ nanohybrid film modified by hydrophobic gold nanoparticles, Appl. Surf. Sci. 333 (2015) 48-53, http://dx. doi.org/10.1016/j.apsusc.2015.01.150.

[32] G. Gauglitz, J. Krause-Bonte, H. Schlemmer, A. Matthes, Spectral interference refractometry by diode array spectrometry, Anal. Chem. 60 (1988) 2609-2612, http://dx.doi.org/10.1021/ac00174a015. 
[33] A.K. Krieg, G. Gauglitz, An optical sensor for the detection of human pancreatic lipase, Sensor. Actuat. B-Chem. 203 (2014) 663-669, http://dx.doi org/10.1016/j.snb.2014.07.036.

[34] N. Leopold, S. Busche, G. Gauglitz, B. Lendl, IR absorption and reflectometric interference spectroscopy (RIfS) combined to a new sensing approach for gas analytes absorbed into thin polymer films, Spectrochim. Acta A: Mol. Biomol Spectrosc. 72 (2009) 994-999, http://dx.doi.org/10.1016/j.saa.2008.12.032.

[35] M. Kasper, S. Busche, F. Dieterle, G. Belge, G. Gauglitz, Quantification of quaternary mixtures of alcohols: a comparison of reflectometric interference spectroscopy and surface plasmon resonance spectroscopy, Meas. Sci. Technol. 15 (2004) 540-548, http://dx.doi.org/10.1088/0957-0233/15/3/006.

[36] M. Vollprecht, F. Dieterle, S. Busche, G. Gauglitz, K.-J. Eichhorn, B. Voit, Quantification of quaternary mixtures of low alcohols in water: temporal-Resolved measurements with microporous and hyperbranched polymer sensors for reduction of sensor number, Anal. Chem. 77 (2005) 5542-5550, http://dx.doi.org/10.1021/ac0504316.

[37] G. Decher, J.D. Hong, J. Schmitt, Buildup of ultrathin multilayer films by a self-assembly process: III. Consecutively alternating adsorption of anionic and cationic polyelectrolytes on charged surfaces, Thin Solid Films 210/211 (1992) 831-835, http://dx.doi.org/10.1016/0040-6090(92)90417-A.

[38] D. Sebők, T. Szabó, I. Dékány, Optical properties of zinc peroxide and zinc oxide multilayer nanohybrid films, Appl. Surf. Sci. 255 (2009) 6953-6962, http://dx.doi.org/10.1016/j.apsusc.2009.03.020.

[39] G. Decher, J.B. Schlenoff, Multilayer Thin Films, Wiley-VCH Verlag GmbH \& KGaA, Weinheim, 2003, http://dx.doi.org/10.1002/3527600574.

[40] A. Deák, I. Székely, E. Kálmán, Zs. Keresztes, A.L. Kovács, Z. Hórvölgyi, Nanostructured silica Langmuir-Blodgett films with antireflective properties prepared on glass substrates, Thin Solid Films 484 (2005) 310-317, http://dx doi.org/10.1016/j.tsf.2005.01.096.

[41] Á. Detrich, E. Hild, N. Nagy, E. Volentiru, Z. Hórvölgyi, Combined Langmuir-blodgett and sol-gel coatings, Thin Solid Films 520 (2012) 2537-2544, http://dx.doi.org/10.1016/j.tsf.2011.10.161.

[42] D. Zhao, Q. Huo, J. Feng, B.F. Chmelka, G.D. Stucky, Nonionic triblock and star diblock copolymer and oligomeric surfactant syntheses of highly ordered, hydrothermally stable, mesoporous silica structures, J. Am. Chem. Soc. 120 (1998) 6024-6036, http://dx.doi.org/10.1021/ja974025i.

[43] S.A. Bagshaw, Morphosynthesis of macrocellular mesoporous silicate foams, Chem. Comm. (1999) 767-768, http://dx.doi.org/10.1039/A901480B.

[44] N.A. Kotov, I. Dekany, J.H. Fendler, Layer-by-layer self-assembly of polyelectrolyte-Semiconductor nanoparticle composite films, J. Phys. Chem. 99 (1995) 13065-13069, http://dx.doi.org/10.1021/j100035a005.

[45] A.M. Youssef, T. Bujdosó, V. Hornok, Sz. Papp, A.F.A. Hakima, I. Dékány, Structural and thermal properties of polystyrene nanocomposites containing hydrophilic and hydrophobic layered double hydroxides, Appl. Clay Sci. 77-78 (2013) 46-51, http://dx.doi.org/10.1016/j.clay.2013.03.011

[46] N. Varga, M. Benkö, D. Sebők, G. Bohus, L. Janovák, I. Dékány, Mesoporous silica core-shell composite functionalized with polyelectrolytes for drug delivery, Micropor. Mesopor Mat 213 (2015) 134-141, http://dx.doi.org/10. 1016/j.micromeso.2015.02.008.

[47] H.-P. Loock, P.D. Wentzell, Detection limits of chemical sensors: applications and misapplications, Sensor. Actuat. B-Chem. 173 (2012) 157-163, http://dx. doi.org/10.1016/j.snb.2012.06.071.

\section{Biographies}

Dániel Sebők (physicist) is a research fellow at the Department of Physical Chemistry and Materials Science at the University of Szeged. He received his Ph.D. degree in Chemistry at the University of Szeged in 2012. Scientific fields of interest: investigation of the interaction of noble metal nanoparticles and biomolecules by Small Angle X-ray Scattering (SAXS) and Surface Plasmon Resonance (SPR), developing of gas- and biosensors using nanohybrid thin films.
László Janovák is an assistant professor at the Department of Physical Chemistry and Materials Science at the University of Szeged. He received his Ph.D. degree in polymer chemistry at the University of Szeged in 2010. Scientific fields of interest: polymer based composite materials for biomedical applications, investigation of superhydrophobic and photocatalytic hybrid surfaces. Teaching of Colloid Chemistry and Macromolecular Chemistry.

Dániel Kovács is an MSc student of Chemistry at the Faculty of Science and Informatics of the University of Szeged. Scientific fields of interest: synthesis, stabilization and industrial application of nanomaterials; preparation and characterization of drug delivery carriers; sensors.

András Sápi is an Assistant Professor of Chemistry at the Department of Applied and Environmental Chemistry, University of Szeged. He received his PhD in 2012 in Chemistry. Dr. Sápi has > 50 scientific publication in the field of nanomaterials and material sciences. His research focuses on size controlled metallic nanoparticles and mesoporous metal-oxides, as well as atomic and molecular level investigation of such materials under reaction conditions in heterogeneous catalysis. He is an expert of surface science and catalysis.

Dorina G. Dobó is a PhD candidate at the Department of Applied and Environmental Chemistry of the University of Szeged. Member of the MTA-SZTE “Lendület" Porous Nanocomposites Research Group at the University of Szeged. Scientific fields of interest: Preparation, characterization and catalytic application of mesoporous oxides synthesized via the soft and hard template method.

Ákos Kukovecz is associate professor of chemistry at the Department of Applied and Environmental Chemistry, Univesity of Szeged, Hungary. He received his Ph.D. in 2001. His research interests are interface phenomena in nanoporous materials, synthesis of low-dimensional materials and sensors. His main instrumental skills are imaging methods and Raman spectroscopy. He is also interested in process plant safety and contract R\&D work for the industry. He currently heads the MTA-SZTE "Lendület" Porous Nanocomposites Research Group.

Zoltán Kónya was born in Hungary in 1971. He received his M.Sc. in 1994, (Chemistry, University of Szeged, Hungary) and Ph.D. in 1998 (Chemistry, University of Szeged, Hungary). He is professor of chemistry and since 2010, he is head of the Chemistry Institute of the University of Szeged, Hungary. Dr. Kónya has published $250+$ papers in refereed scientific journals and co-authored 15 book chapters. He holds 12 national and international patents. His research interest is the development of new nanostructured materials and their application to real chemical, environmental, biological and biomedical objects.

Imre Dékány is full professor of chemistry at the Department of Physical Chemistry and Materials Science, and the head of the research group on the Department of Medical Chemistry, Faculty of Medicine, University of Szeged. He is member of Hungarian Academy of Sciences since 2001. Research interest: colloid and interface chemistry and nanostructured materials. Member of the editorial board of Applied Clay Science. He has published over 360 papers, 12 book chapters, he is inventor of over 25 patent applications. The total number of citation of his papers and books is $10000+$ and his H index is 50 . 